University of Louisville

ThinkIR: The University of Louisville's Institutional Repository

Electronic Theses and Dissertations

$1-1926$

\title{
The influence of sixteenth century voyages on Elizabethan literature.
}

Elizabeth Nugent

University of Louisville

Follow this and additional works at: https://ir.library.louisville.edu/etd

\section{Recommended Citation}

Nugent, Elizabeth, "The influence of sixteenth century voyages on Elizabethan literature." (1926).

Electronic Theses and Dissertations. Paper 1073.

https://doi.org/10.18297/etd/1073

This Master's Thesis is brought to you for free and open access by ThinkIR: The University of Louisville's Institutional Repository. It has been accepted for inclusion in Electronic Theses and Dissertations by an authorized administrator of ThinkIR: The University of Louisville's Institutional Repository. This title appears here courtesy of the author, who has retained all other copyrights. For more information, please contact thinkir@louisville.edu. 


\title{
UNIVERSITY OF LOUISVILLE
}

THE INFLUENCE OF SIXTEENTH CENTURY VOYAGES

ON ELIZABETHAN LIT RRATURE

\author{
A Dissertation \\ Submitted to the Faculty \\ Of the Graduate School of Arts and Sci ences \\ In Partial Fulfillment of the \\ Requir ements for the Degree of \\ MASTER OF ARTS \\ Department of English
}

By

Elizabeth Mugent

1926 
THE INFLUENCE OF SIXT EENTH CENTURY VOYAGES

ON ELIZABETHAN LIT RRATURE

It is the purpose of this thesis to show what influence the sixteenth century voyagers had on the Elizabethan writers. For expedi ency, we have divided these voyages into two classes: namely, the early, from Columbus, 1492, to Vasca de Gama, 1498; and the later voyages from de Gama to Gaptain Smith, 1603.

We find that commerce instigated nearly all early navigation. The Turks having out off the Mediterranean trade route with India in 1453 , it was necessary to find another water route to this country. As a direct consequence, Columbus discovered the West Indies in 1492 and claimed the new found land for Spain. John Cabot in 1497 claimed the north mainland of America for mgland. Vasca de Gama in 1498 finally fulfilled the prime purpose by reaching India via the water route and claimed this honor for Portugal. Commerce ceased to be the sole motive for the later voyages. Adventure, "quick weal th", and new world supremacy among Furopean nations were at the bottom of all sixteenth century navigation. The three great powers England, France, and Spain - were pitted against one another in this tremendous struggle. England's part in the affair, having direct bearing on our subject, makes us confine ourselves to those Elizabethan "Sea-Dogs" who 
won their country's way into Spain, France, and Portugal's new world possessions. With reference to this thesis, the question arises, what effect did their voyages have on the literature of the period?

To answer this we shall take up for brief discussion the published journals of Sir John Hawkins, Sir Walter Raleigh, Sir Francis Drake, Sir Humphrey Gilbert, and Richard Eden. The stories of many of these voyages were carried by "word of mouth"; and their nature, or how far-reaching their influence, it is impossible to d et ermine.

Sir John Hawkins was one of the first sixteenth century navigators who resolved to break down the barriers against English settlements in the new world. He made three voyages to Brazil and the coast of Guinea in 1562, 1564, and $156 \%$. The third voyage was written and published by Hawkins in the year of his return - 1568. From the title we learn the hardships of that trip: A true declaration 으 the Iroublesome voyage of $\mathrm{Mr}$. John Hawking to the parts of Guinea and the West Indies in the years of our Lord 1567 and 1568.

Sir Francis Drake, a kinsman of John Hawkins, like most men of action, had little time for literature; and the task of writing an account of his voyage devolved 
on Master Francis Fletcher, the clergyman who accompanied him. "To stirr up heroick spirits and to benefit their Countrie"l, was Drake's purpose in this publication. In the dedicatory epistle to Robert Earle of Warwick, he writes: "I am pleased if the reader can pick out either use or content." (1) Then as a check on possible emulators, he warned "that Columbus did neatly check his emulators, by rearing an egg without assistance. Let the slighter of this voyage apply."(1)

To ease the scrupulous English conscience and to encourage among his fellow men the "Adventurer's trade", Drake wrote that "the main ocean is the Lord's alone, and by nature left free for all men to deale withall ........ and large enough for man's industry."(3) Drake adhered to this idea when he drove out his feilow European colonizers in the new world.

Sir Humphrey Gilbert and his half brother Sir Walter Raleigh have left jounals of their voyages which reflect the public interest in their enterprises. A Discourse of a Discoverie for a new passage to Gataia was written by Gilbert in April, 1576, purposely to arouse interest in the "north-west passage". Gilbert

I Sir Francis Drake, The World $\frac{\text { Encompassed (Dedicatory Epistle) }}{\text { Hakluyt }}$

2 Sir Francis Drake, The Tlorld Encompassed (vol. XVI, p.6) Hakluyt Publications. 
was anxious to incite the English against the Spanish and in 1577 published a discourse on How her Majesty might annoy the King of Soain by fitting out a fleet of war shios under pretense of a voyage of discovery, and so fall upon the enemy's shipping, destroy his trade in New Foundland and the West Indies and possess both regions. In 1588, Sir Gilbert's Voyage to Newfould was written by Sir glward Haiss. "Thus have I delivered, "writes the author, "the contents of the enterprise and last action of Sir Humphrey Gilbert ........ wher ein may alwai es appear ...... some sparks of his vertues, he remaining firm and resolute in purpose ...... to reduce unto the service of God and Christian piety, those remote and heathen countries of America ....... most rightly appertaining to the Crowne of England."(1)

Sir Walter Raleigh, half brother of Sir Humphrey Gilbert, figures in English history in the roles of explorer, colonizer, and man of letters. The only writings dealing with navigation that were written by Raleigh and published during his life were an Account of the Azores, 1591, History of the World 1614, and the Discovery of Guiana, 1596. The full title of the first mentioned work is A Report of the Imuth of the Fight about the Isles of the Azores, the last of August 1591: Between the Revenge

1 Sir Humphrey Gilbert's "Voyage to New Foundland" (Old South Leaflets No. 118, p. 31). 
one of Her Majesty's shins, and an Armada of the King of Spain: penned by the Honourable Sir Walter Ralegh. The object of this report was to convine the English public "that the Spaniards according to their usual manner, fill the world with their vain glorious vaunts, making great appearances of victories, when, on the contrary, themselves are most commoniy and shamefuily beaten and dishonoured ...."( 1)

The second work from Raleigh's pen is his Discovery of the large, rich and beautiful Fmpire of Guiana, with a Relation of the great and golden city of Manoa. The English populace demanded some written account and explanation of the wonders which Raleigh claimed he had seen. The work stirred up public sentiment; and as a result, we have chapman's De Guiana Carmen, written in 1596 and extolling Raleigh's attempt to add more glory to his loved England. The History of the World was published in 1614. As a piece of historical writing, this work holds a significant place. Besides valuable information coneerning the new world which is interspersed throughout the five books, we glean political developments of Raleigh's day. He proves that a Council of Indies existed during the reigh of Henry VIII. "Franci sco Lopez," says Raleigh, "wrote the navigation of Or ellana, which he made of the River Amazon from Peru 1543, reports from the relations of said Orellana to the Council of Indi es." (2)

1 Sir Walter Raleigh's Report on the Azores etc. (Pinkerton's Voyages and Travels, vol. 1, p. 824).

2 Sir Walter Raleigh, History of the World (vol.2,bk.IV,p.478). 
A place beside Raleigh in the literature of navigation and discovery must be accorded Richard Eden, sometimes called the precursor of Hakluyt. Translations from Latin, Spanish, Italian, and Portuguese make up the bulk of Eden's literary contributions. In 1553, he translated from the Latin of Sebastian Munster The Universal Cosmography, A treatise of the newe India with other newe founde lands and Islands, as well eastward as westward, as they are known and founde in these our days. Close to this publication, Decades of the Newe World or West India appeared in 1555. This work is also translated from the Latin of Peter Martyr of Angleria. In 1561, The Art of Navigation was translated from the Spanish manusoript of Martin Cortez and published by Eden. When Hakluyt began his compilation, there was only one English book which gave knowl alge of maritime discovery. This work was Eden's History of Travayle in West and East Indies ..... published in 1577 . It contains the translation of Antonio Pigafetta's account of the ciroumnavigation of the globe by Magellan. The influence of this work is undoubtedly seen in Shakespear e's The Tempest.

Richard Hakluyt continued the work begun by Fien by collecting voyages from other countries as well in England. Four publications were put out by Hakluyt 
in the years 1582, 1587, 1598, and 1600. Before considering these publications it will not be amiss to see what connections, social and literary, Hakluyt had with the men of his day. In the prefaces of the various editions of the Voyages appear the names of Phillip Sidney, Dyer and Walter l eigh. Hakluyt dedicated The Divers Voyages to Phillip Sidney and may have persuaded him to invest in Virginia colony. (1) Dyer encouraged him in the writing and collecting of mamuscripts, but how, is not told. (2) Raleigh was a great patron of Hakluyt, and the latter's edition of 1587 is dedicatel to him. (3) Hakluyt collected colonial information for Raleigh in Paris and wrote for him the Discourse on Western Planting, also an address to the Queen urging royal support of Virginia. Robert Cecil was a great benefactor of Hakluyt. Besides political and literary men, Hakluyt had a wide circle of friends who worked in the geographical field: Florio, Michael Lock, Parmenius, Marc Antonio Pigafetta, author of an overland voyage from Vienna to Constantinople and many other places, and Samuel Purchas, who borrowed a considerable portion of Hakluyt's works for his own collections.

1 Feuillerat's Works of Sidney, vol. 3.

2 Richard Hakluyt, Preface to 1589 ed. Of Voyages

3 Richard Hakluyt, Preface to 1587 ed. of Voyages 
The names of the four famous publications which gave England a complete geographical library in 1600 were Divers Voyages.... 1582; A Notable Hi story..... unto Florida......1587; Principall Navigations...... in three volumes and published in 1589, 1598, 1600; The Discoverie of the World....1601. The last work of Hakluyt was Virginia Richly Valued, which appear ed in 1609. Having given a brief outline of the travel literature ourrent in the day of Elizabeth, we can determine definitely that some of it must have fallen into the hands of the literati. It will be seen in the reviews of the following Elizabethan writers that they had a fair knowledge of Hakluyt and other compilers of maritime voyages. Fdmund Spenser (1553-1599) is one of the earliest Elizabethans to feel the for eign influence. His interest in the new world was partly due to his great friendship with Sir Walter Raleigh, on whom he bestowed the title of "Shepherd of the Ocean". Colin Clout's Come Home Again, the poem in which this title is found, was written by Spenser a fter a visit to Elizabeth's Cout and was dedicatted to Raleigh. The latter paved the way for a lasting friendship between Spenser and the Queen.

The following passage from Colin clout gives 
evidence of the chance meeting between Spenser and Raleigh:

"Keeping my sheep amongst the cooly shade Of the green alders by the Mulloes shore There a strange Shepherd chaunst to find me out, Whether allured with pipes delight, Whose pleasing sound yshrilled far about, Or thither led by Chance, I know not right;

Whom when I asked from what place he came, And how hight, himself did ycleepe The Shepherd of the Ocean by name, And said he came from far, from the main-sea deepe." (1)

When Spenser began his Faerie Queene, about 1580, he was intimately associated with Sir Phillip Sidney, Captain Christopher Carleel, son-in-law of Walsingham, a man who gained great distinction both on land and sea, serving the English in the Low Countries, France, and San Domingo; and Sir Walter Raleigh.

Ludowick Bryskett, a predecessor of Spenser in the service of the Council of Munster, writes in a Discourse on Civil Life, 1606 of a meeting at his home near Dublin at which Spenser and the above mentioned men were present. This undoubtedly shows that Spenser had ample opportunity to

1 Edmund Spenser, Colin Glout's Come Home Again (lines 57-66). 
learn of the $\mathbb{N}$ ew World.

Two survivals of chivalry existed in the Elizabethan period,-one real, the other formal. The real alone has a bearing on our subject; it was the spirit of armed adventure which sent the knights of Elizabeth's court, as audacious sailors, to explore unknown seas and plunder the Spanish treasure ships. That Spenser was in actual contact with many of the seafarers is indicated by the following references to the new world in the Faerie Queene:

"Right well I wot, most mighty Soveraine,

That all this famous antique history

of some th' abundance of an ydle braine

Will judged be, and painted forgery,

Rather than matter of just memory;

Si th none that breatheth living aire does know,

Where is that happy land of Faery,

Which I so much doe vaunt, yet no where show,

But vouch antiquities, which no lady can know." (I)

II

"But let that man with better sence advize,

That of the world least part to us is rid,

And daily how through hardy enterprise

Many great regions are discover ed,

Which to late age were never mentioned.

Who ever heard of th' Indian Peru?

1 Edmund Spenser, Faerie Queene (Bk.11, Canto 1, Introd. 1-2). 
Or who in venturous vessel measured

The Amazons huge river, now found true?

Or fruitfullest Virginia who did ever view?

Yet all these were when no man did them know,

Yet have from wi sest ages hidden beene

And later times things more unknowne shall show."(I)

While Spenser was writing the Faerie Queene,

Raleigh was closely associated with him in Diblin.

But in spite of the conversations which Spenser must have had with Raleigh concerning the new world, we find only two direct $r e f e r e n c e s$ to America in the Faerie Queene:

\section{IXXI}

"That man 80 made he called Elfe, to weet Quick, the first author of all Elfin kynd:

Who wandering through the world with wearie feet, Did in the gardens of Adonis fynd, A goodly creature, whom he de med in mynd. To be no earthly wight, but either spright Or angell, th' authour of all woman kynd, Ther efore a Fay he her according hight, of whom all Faryes spring and fetch their linage right." (2)

I Edmund Spenser, Faerie Queene, (Bk.11, Canto II).

8 I bid. (Canto LXXI). 
"Of these a mighty people shortly grew, And puissant kings, which all the world arrayd, And to themselves all nations did subdew.

The first and eldest, which that scepter swayed, Was Elfin; him all India obayed, And all that now Anerica men call: But Elfline enclosed it with a golden wall." Thomas Lodge (1554-1625), a precursor of Shakespere and a dramatist of no mean ability, wrote his Margarite of America, 1596, during an expedition into the Straits of Magellan. The story, though written in the New World, has 0ld World background and only in the Dedications and Lyries, interpolated by Lodge, can we trace the influence of his visit to foreign shores. In the Dedication to Lady Ruffles, we note a description of Patagonia:

"In which place to the Southward many wondrous Isles, many strange fish, many monstrous Patagonias withdraw my senses; briefly many bitter and extreme frosts at midsummer continually clothe and clad the discomfortable mountains; so that as there was great wonder in the place wher ein I writ this so likewise might be marvelled, 
that in such scantie fare, such causes of fear so mightie discouragement and many crosses, I should deserve or eternize any thing." (1)

Again in the Dedication to the Gentlemen, Lodge gave London an opportunity to know what hardships were endured by those who braved the deep to add new glories to Elizabeth's orown:

"The place where I began my worke, was a ship, where many soldiers of good reckning finding disturbed stomackes ....... the time I wrote in was when I had rather will to get my dinner than to win my fame..... In a word, I wrote und er hope, rather the fish should eat both me writing, and my paper written, than fame should know me; hope should accquaint her with me, or any but misery whould hear mine ending." (a)

We note.in the Lyrics in the Margarite of America a bit of the foreign flavor and the influence of Lodge's new surroundings.

\section{Dolores.}

"As is the might unto the sandie seas As is the drop unto the Ocean streams

Even such is thought than vainly doth endure, To think that care lives here, or counted ever."

I Thomas Lodge, A Margarite of America - Dedication to Lady Ruffles.

2 Thomas Lodge, A Margarite of America - Decidation to the Gentlamen. 
In the next verse we feel that the "Dolores" might have been personal experiences of the dramatist.

"Here sorr ow, plague, despair and fierce suspect, Here rage, jelousie, treason and neglect

Have left their stings to plague a wo eful night." "The following was written," says Lodge, "in an amorous and more plausible vain (as that which most pleased the ladies) and was not of least worth, I have set down last."

"Ye gentle pearls where ere did nature make you? or whether in Indian shores you found your mould. Or in those lands where spices sure for fuel; 0! if I might from out your essence take you. And turn myself to shape what ere I would How gladly would I be my Ladies jewel." Thomas Kyd (1558-1594), the dramatist who dealt largely in "blood and death", shows in his writings that he was conscious of the influx of wealth into the Spanish coffers from her new world possessions.

In the first part of I eronimo $1605 \mathrm{we}$ find this reference to Spain and her opulent Indies:

".................... trybute?

Alas, that Spain cannot of peace forbear A little coin the Indies being so near."(1)

Thomas Kyd, I eronimo (Act 1, sc. 2). 
Again in Act III, scene 11 is the refer ence to the Indian mines.

"Lor enzo' $s$ bounty, I do more enfould

Than the greatest mine of Indian brightest gold."

The wealth of the Indies was an established fact

in Europe, especially after the discovery of the Potosi mines in 1545, which kept a continual stream of gold flowing into the Spanish treasury. Hakluyt published the Report of Francisco Xeres who makes special mention of the wealth of the Incas mines. The work was published by Hakluyt in 1587 .

The following passage is tak on from the Report:

"In all provinces of the Incas there are many mines of gold and silver. They get the gold out of the mountain with little trouble, one Indian getting five or six marcs in a single day." (1)

George Chapman (1559-1634) belongs to the Golden Age poets and used his facile pen to immortalize Raleigh's Guiana expedition. De Guiana Carmen Epicum 1596 was a laudatory tribute to the "Eliza consecrated sword of Raleigh". In a poem of some three hundred lines, the poet takes advantage of the muse to score

1 Richard Hakluyt, Report on Peru (p.63). 
the incredulous, who, we judge, must have mocked the attempts of Raleigh to colonize Guiana.

In the opening lines, we observe the poet's notion of the beauty of Guiana:

"Guiana whose rich feet are mines of gold, Whose for eh knocks against the roof of stars, Standing on her tip toes at fair England looking, Kissing her hand, bowing her mighty breasts, And every sign of all submission making To be her sister, and the daughter both, of our most sacred maid." (1)

Chapman then begins an attack on the en enies of Raleigh, who doubted the truth even after Raleigh's own account written and published after his return in 1596 . (2)

"O incredulity! the wit of all things fair, The cowards castle and the sluggard's cradle, How easy 'tis to be an infider." (3)

A Masque of Virginia $1613^{(4)}$ was written by Chapman for the Middle Temple and Lincoln's Inn. The plot is based on the historical incident of the Indian King Powhatan and the capture of his famous daughter Pocahontas by the English settlers. Captain John Smith

1 George Chapman, De Guiana Carmen Eoicum (1ines 1-7).

2 Sir Walter Raleigh, Di scovery of the large, rich and beautiful Empire of Guiana $(1596)$, Hakluyt Pubilcations, V01.3.

3 George Chapman, De Guiana Carmen Eoicum (1ines 14-17).

4 Mary Sullivan, Court Masques of James I (p. 73). 
was representing the English crown in America, and the news of his daring deeds found their way back to England. There was also a rumor that Powhatan offered to show the settlers some gold mines in Virginia upon the release of his daughter.

The Venetian ambassador at the Court of James I gives the following notification to his government of the performance of the Masque:

"First came a hundred gentlemen on horseback, accompanied by a hundred grooms with lights in their hands. Then followed a little Masque on hor seback with a large number of torches all alone; then two triumphal cars with musicians dressed in silver with turbans on their heads. These represented the priests of the Sun in Virginia. Then came the great Masque, all being dressed in cloth and silver, golden suns and plumes. They represented Princes of Virginia with crowns of feathers and pearls on their heads, and their hair down to their shoulders as is the custom of that country; their horses too were all caparisioned in silver and suns.

"Then came a hundred blacks dressed in gold and blue, the dress of Indian slaves. Then came a great number of lights borne by men on horseback, dressed in 
silver and gold, like the great Masque except the crowns. Then a triumphal car with figures inside representing Honour and Riches and round it marched two hundred halberdiers. When the King enter ed the Hall one saw a mountain all full of crags and on top the Temple of Honour, made of silver; and octagon with silver statues round the cornice; on its summit two golden wings sprang from a silver ball, signifying that Fortune and her son Honour had resolved to settle forever in this kingdom. Hard by the temple was a woods and in it a huge treetrunk which contained the whole of the little Masque. Hardly had the King appeared when the crags came forward five paces towards his Majesty; Clouds gathered and the mountain split, and there appeared a rich mine of gold with all the Masque inside and a vast number of torches; it all took place in a moment. Then appeared the sun as at its setting; the priests adored it and part of them sang to lutes; they were answered by voices and instruments from the Temple, and from other parts of the Hall. Then Riches began to speak and again the crags moved; then after great eulogies of the couples, pronounced by Riches and Honour, all the Masque began to dance a ballet, with such finish that it left nothing to be desired." (1)

1 Antonio Fogcarini to the Doge and Senate, 10 May,1613, in Calendar of State Papers Venetian, XII, 531, No.832. 
We cite the discourse written by Captain John Smith (1608) A true relation of such Occurrences and Accidents of Note as hath passed in Virginia since the first planting of that colony, as possibly having some influence on Chapman's Masque. The account of the capture of Pocahontas is included in Smith's General History of Virginia, NeN England and the Summer Isles published in 1625. The publication was too late to have had any influence, but we quote the following passage from the General History of Virginia Etc. to prove that Chapman's plot had historical basis. "Captain Argall ...... was sent to conclude our peace and thus it happened. Captain Argall having entered into a great acquaintance with Iapazaw, and an old friend of Captain Smith ........ Pocahontas, whom Captain Smith's relations entitled the nonpar eil of Virginia ....... was never seen at Jamestown before and ....... was by her friend Iapazaw, easily persuaded to go aboard with him and his wife to see the ship, for Captain Argall had promised him a copper kettle to bring her to him, promising no way to hurt her, but keep her till they could conclude a peace with her father ...... At last he (Iapazaw) betray ed the innocent pocahontas aboard, where they were all kindly treated in the cabin ....... The Captain persuaded 
Pocahontas to the gun room ...... and told her before her friends she must go with him, and compound peace between her country and us, before she ever should see Powhatan ...... A messenger was sent to her father, that his daughter, Pocahontas he loved so dearly, he must ransom with our $m e n$, swords, pieces, tools etc. he treacherously had stolen.

"It was three months after ere he returned any answer, then by persuasion of the council, he returned seven of our men, with each an unservicable musket, and sent us word that when we should deliver his daughter, he would make us satisfaction for all injuries done us, and give us five bushels of corn and forever be friends wi th us. That he sent we received in part payment but we could not believe the rest of our arms were either stolen or lost from him, and therefore till he sent them we would keep his daughter."

The marriage of pocahontas with JOhn Ralph finaliy concluded the peace, but minus the promises which the English had demanded. "But," says Smith, "ever since we have had friendy trade and commerce, as well with Powhatan himself as all his subjects." (1)

Francis Bacon (1561-1626), the scientist-philosopher

1 Captain John Smith, General History of Virginia, New Ingland and the Summer Isles. (PInkerton's General Collection of Voyages, pp.111, 112,113). 
of the sixteenth century, put forth many theories concerning the new world. Some of his suggestions were carried out in the real sense by Drake and in the formal sense by Hakluyt in his translations and compilations.

In the NeW Atlantis, 1624 , Bac on expresses his belief in the existence of a southern continent, supposed by some scholars to be the present Australia. With his knowledge of science, Bacon worked out an ideal commonwealth, supplying the gaps in his theories by the reading of the numerous travels and voyages then published.

The opening chapter of the New Atlantis gives us Bacon'g notion of the Nova Terra:

"We sailed from Peru, where we had continued by the space of one whole year, for China and Japan, by the South Sea, taking with us victuals for twelve months; and had good winds from the east through soft and weak for five months space of more." (1)

From the above passage we infer that Bacon had a fair knowledge of geography and was placing Japan and China in their proper location. The exact position of Bacon's continent which he calls the New Atlantis is impossible to determine, but the

1 Francis Bacon- The NeW Atlantis, p. 103, Ideal Commonwealths, World's Greatest Lit. pub. 
locale and background have a distinctly Peruvian touch. The following description in the New Atlantis of the wines and fruits found in this ideal commonwealth are nearly identical to those mention in the report of Francisco Orellana concerning the Valley of the Amazons, which is contained in the sixth decade of A. de Herrara's General History of the Western Indies. This work was published prior to 1625 .

"We had also drink of three sorts, all wholesome and good; wine of the grape; a drink of grain, such as is with us our ale, but more clear; and a kind of cider made of the fruit of that country, a wonderful pleasing and refreshing drink. Besides, they brought u.s great store of scarl et oranges for our sick. n(1) The following is a description of the ale making taken from the report of Francisco Orellana: "The men found maize and Castilian oats of which the Indians made a liquor like our beer ... they also make other kinds of wine of wild fruits which abound on the trees; they are so fond of drunkenness. They put juice into water and produce a liquid which often exceeds our beer in strength." (2)

The destruction of the New Atzantis was due

1 Francis Bacon - The New Atlantis (p.105-6)Ideal

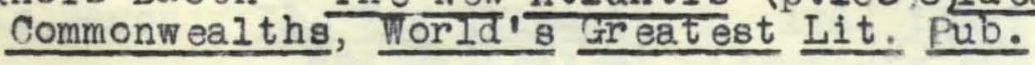

2 Richard Hakluyt, "Report of Franci sco Orellana", The Valley of the Amazons, Hakluyt Publications, Vol.24, p.33. 
to the floods of the bays and river, writes Bacon. In Samuel Purchas His Pilgrims (1613) we find a passage describing similar floods in the NeW World.

We quote the following description of the New Atlantis:

"For within less than the space of a hundred years the great Atlantis was utterly destroyed; not by a great earthquake, as your man saith, for that whole tract is little subject to earthquakes, but by a deluge, or inundation; those countries having at this day far greater rivers, and far higher mountains to pour down waters, than any part of the old world... it destroy ed man and beast generally, yet some wild inhabitants of the wood escaped. Birds also were saved by flying to the high trees and woods." (1)

Samuel Purchas in His pilorims (1613) gives the following account of a flood in the New World:

"These rains make like inundations and overflowing of the Rivers of America ...... which breaking their bounds and driving the Inhabitants sometimes to dwell on tre

It is undoubtedly true that this work of Bacon was justiy valued in his day, enjoying a wide

1 Francis Bacon, The New Atlantis, p. 116, Ideal Commonweal ths, Worlas Greatest Li terature Publication

2 Samuel Purchas, Hig PilgrimB 1613 (E1ghth Bk., Chap. 1, p. 604, 
circulation for its account of the new world.

Michael Drayton (1563-1631) was conscious of the British struggle to colonize the new world when he wrote his famous ode - To The Virginian Voyage 1606. It reveals the spirit of Elizabethan patriotism and adventure despite the fact that James I had snubbed Drayton's literary attempts. The Ode is a glorious call to bravery and heroic deeds.

"Britons, you stay too long Quickly aboard best ow you, And with a merry Gale, Swell your stretch's Sayle, With vowes as strong, As the Winds that blow you.

And cheerfully at Sea Successe you still intice To get the Pearle and Gold, And ours to hold, Virginia, Earth's on ely Paradise.

And as there Plenty prowes Of Lawrell every where, Apollo' s Sacred tree You may it see A Poet's browes To orown, that may sing there." 
Christopher Marlowe (1563-1593), another of the greater Elizabethan dramatists, shows himself to be familiar with the explorations and discoveries of the period in his famous Tamburlaine, which is based on Pedro Mexea's life of Timur, the Oriental Conqueror. The date of the publication of Marlow $e^{\prime} s$ Tamburlaine is supposed to be around 1585. The notions Marlowe had acquir ed of the new world must have been derived from $v$ ery early documents, as the big editions of Hakluyt and Purchas were not published until 1589 and 1613 respectively.

We note in the following speech of Tamburlaine the accuracy of Marlowe's knowledge of the circumnavition of the globe:

"Those walled garrisons will I subdue, And right myself great Lord of Africa.

So from the past unto the furthest West, Shall Tamburlaine ext and his puissant arm. The galleys and those pilling brigandines That yearly sail to the Venetian Gulf And hover in the straits for Christians wreck, Shall lie anchor in the isle of Assant Until the Persian fleet and $m$ en of war Sailing along the Oriental Sea 
Have fetched about the Indian continent. Even from Persopolis to Mexico. And thence into the Straits of Jabrailtar Where they shall meet and join their force in one. Keeping in awe the bay of portingale And all the ocean by the British shore, And by this means I'II win the world at last." (1) In Act $V$ we find a servant fetching a map for Tamburlaine which gives the student of Marlowe a hint as to the latter's geographical knowledge. While not plentiful nor perfectly accurate, there were maps drawn and published that could have given Marlowe much information on the exact locations of the new continents.

The following is a passage from Tamburlaine's famous march:

"Here, I began to march toward Persia Along Armenia and the Caspian Sea And thence unto Bethynia, where I took The Turk and His great Fmpress prisoners. And here not far from Al exandria, Whereas the Terr ene and the Red Sea meet. Being less distant than full a hundred leagues, I meant to cut a channel to them both

1 Christopher Marlowe- Tamburlaine, Act III, sc. 3, Pt. I. 2 See maps in Hakluyt's Divers Voyages, 1582. 
That men might quickly sail to India,

From thence to Nubia near Borneo's Lake,

And so along the A ethopian Sea,

Cutting the Tropic line of Capricorn,

I conquered all as far as Zanzibar

Then by the Northern part of Africa

I came at last to Graecia, and from thence

To Asia, where I stay against my will

............ see what a world of ground

Li es westward from the midst of Cano er's lane Unto the rising of this earthly globe." (1)

The reference to the channel was undoubtedly inspired by Vasco da Gama's new route to India via the Cape of Good Hope (1497). As this question of a new route to India began in the period of navigation and di scovery, so it continued in liarlowe's day. A channel into the Red Sea was never attempted by Europeans, but the Ancient Ptolemys in 1394 B.C. began a channel at the present site of the Suez Canal.

William Shakespere (1564-1616) shows his interest in and knowledge of discovery and exploration by his frequent references to the New World. His possible association with Raleigh and Drake at the

1 Christopher Marlowe - Tamburlaine, Act V, sc. 3. 
various taverns might have influenced him, but Shakespere was prone to find out for himself. His familiarity with the New World leads us to beli eve that he thumbed well Hakluyt's manuscripts and as many original works as he could find.

\section{In the Cormedy of Errors (1592):}

Dromio of Syracuse - "Where's America, the Indies?" Antipolus of Syracuse - "O sir, upon her nose, all

o'er embellished with rubies, carbuncles, sapphires, declining the rich aspect to the hot breath of Spain, who sent whole arma of corracks, to be ballast at her nose." (1)

In the Merry Wives of Windsor (1601):

Falstaff - "Here's another letter to her; she bears the purse too; she's a region in Guiana all gold and beauty. I will be cheater to them both; they shall be my East and West Indies and I will trade to them both ......" (a)

In $\perp$ Midsummer Night's Dream (1594):

Oberon - "Tarry, rash wanton. Am I not thy lord?" Titania- "Then I must be thy lady; but I know When thou hast stol'n away from fairy land And in the shape of Corin sat all day,

1 William Shakespere- Comedy of Errors, Act III, sc.2, lines 136-141 2 William Shakespere- Merry Wives of Windsor, Act I, sc.iii, lines 74-79. 
Playing on pipes of corn, and versing love

To amorous Phillida. Why art thou here,

Come from the farthest steppe of India,

But that, forsooth, the bouncing Amazon,

Your buskin'd mistress and your warrior love,

To Theseus must be wedded, andyou come

To give their bed joy and prosperity." (1)

In the Merchant of Venice (1597):

Shylook - "He (Antonio) hath an argosy bound for

Tripolis, another for the Indies ...... a

third bound for Mexico ...... " (z)

In Twelfth Night (1613):

Maria - ${ }^{H e}$ (Malvolio) does smile his face into

more lines than are in the new map, with

the augmentation of the Indies ......" (3)

Malone, the Shakespear ean scholar, believes this map to be the one published by Hakluyt in 1598. The map was included in his translation from the Dutch of Linschoten's Discourse of the East and West Indies.

In othel10 (1604):

Othello - ".....the cannibals, that each other eat,

The Anthropophagi and $m$ en whose heads

Do grow beneath their shoulders, ,...." (5)

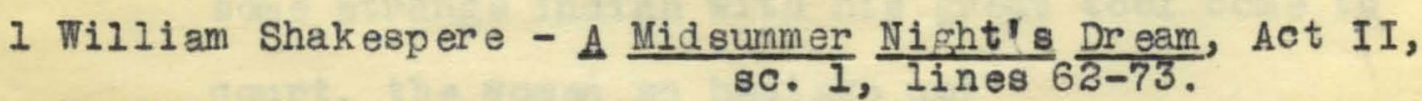

2 William Shakespere - A Merchant of Venice, A ct I, sc.iii,lines 18-21.

3 William Shakespere - Twelfth Night, Act III, sc.ii,lines 83-86.

4 See Introduction to Twelfth Night in Malone Edition of Shakespere.

5 William Shakespere - 0thel10, Act I, sc.iii, lines 142-144. 
Shakesper e s knowledge of this barbarous tribe was possibly derived from Raleigh's Discovery of Guiana 1595. Raleigh writes of the"Ewaipanowa which are those wi thout heads....... The Coors (a nation of this tribe) whose heads appear not above their shoulders." (1)

In Macbeth (1606):

Macduff - "Bleed, ble ed poor country Great tyranny, lay thou thy basis sure,

I would not be the villain that thou thinkest, For the whole space that's in the tyrant's grasp, And the rich East to boot." (2)

The "East" referred to is undoubtely the Indies, which had become at that time a synonym for wealth. In Henry VIII (1603)- (Coronation Scene):

1 Gent. - "Heaven bless thee! (looking at the Queen) Thou hast the sweetest face I ever looked on Sir, as I have a soul, she is an angel Our king has all the Indies in his arms, And more and richer, when he strains that lady. I cannot blame his conscience." (3) Again in Act $\mathrm{V}$, sc. 3 :

Porter - "Is this Moorfield to muster in? Or have we some strange Indian with his great tool come to court, the women so besiege us?"

1 Sir Walter Raleigh- Discovery of Guiana, p. 86.

2 William Shakesper e- Macbeth, Act IV, sc. 3, lines 32-38.

3 William Shakespere- Henry VIII, Act IV, sc. 1, lines 45-48. 
The Tempest (1610?) is considered by such eminent critics as George Wyndham and George W. Cooke to be a direct outgrowth of the voyagers' literature. Caliban and Caliban's god Setebos, according to Mr. Cooke were characters taken from Antonio Pigafetta's Journal of Magellan's circumnavigation of the globe. This Journal was translated from the Italian in 1577 by Richard $\mathrm{Bden}$; and $\mathrm{Mr}$. Cooke, to prove his statement, quotes the following account from when which contains a description of Shakespere's Setebos:

"After another fifteen days were past, there came four other giants without any weapons but had hid their bows and arrows in certain bushes. The Captain retained two of these which were youngest and best made. He took them by a deceit in this manner, that giving them knives, shears, looking glasses, bells, heads of orystal, and such other trifles, he so filled their hands that they could hold no more. Then caused two pairs of shackles of iron to be put on their legs, making signs that he would also give them those chains; which they liked very well because they were made of bright and shining metal. And whereas they could not carry them because their hands were full, the other giants would have carried them; but the Captain would 
not suffer them. When they felt the shackles fast about their legs they began to doubt; but the captain did put them in comfort and bade them stand still. In fine, when they saw how they were deceived they roared like bulls and cried upon their great devil Setebos to help them. Being thus taken they were immediately separated and put in sundry ships. They could not bind the hands of the other two. Yet was one of them with much difficulty overthrown by nine of our men and his hands bound; but he suddenly 100 sed himself and fled as did also the other that came with them. In their flying they shot of their arrows, and slew one of our men. They say that when one of them die, there appear ten or twelve devils leaping and dancing about the body of the dead, and seem to have their bodies painted with divers colors. And that among others there is one sun bigger than the residue, who maketh great mirth and rejoicing. This grea't devil they call Setebos and call the lesser Cheleule. One of these giants which they took declared by signs that he had seen devils with two horns above their heads, with long hair down to their feet; and that they cast forth fire from their throats both before and behind. The Captain named these people Patagoni. 
The most of them wear the skins of such beasts whereof, I have spoken before; and have no house of continuance, but make certain cottages which they cover with the said skins, and carry them from place to place. They live on raw flesh and a certain sweet root they call capar. One of these which they had in their ships did eat at one meal a basket of biscuits and drank a bowl of water at a draught."

Shakespere mentions Setebos only twice in The Tempest, - Act I, scene ii, lines 372-375. Caliban "No, pray thee.

I must obey; his art is of such power,

It would control my dam's god, Setebos,

And make a vassal of him."

Prospero - "So, slave; hence! "

Again in Act $V$, soene 1 , lines $261-263$.

Caliban - "O Setebos, these be brave spirits indeed!

How fine my master is! I am afraid

He will chastise me."

The electric display described by Ariel

in The Tempest conforms in a great measure to William Strachey'g account of these "strange lights":

Ariel - "All hail, great master! grave sir, hail! I come To answer thy best pleasure; be't to fly, To swim, to dive into the fire, to ride 
On the curl'd clouds, to thy strong bidding task Ariel and all his quality."

Prospero -

"Hast thou, spirit,

Perform'd to point the tempest that I bade thee?" Ariel -"To every article.

I boarded the king's ship now on the beak, Now in the waist, the deck, in every cabin,

I flamed amazement: sometime I'd divide, And burn in many places; on the topmast, The yards and bowsprit, would I flame distinctly, Then meet and join. Jove's lightnings, the precursors $0^{\prime}$ the dreadful thunder-claps, more mom en tary And sight-outrunning were not; the fire and cracks of sulphurous roaring the most mighty Neptune Seem to besiege and make his bold waves tremble, Yea, his dread trid ent shake." (1)

From Strachey's account:

"Upon Thur sday night Sir George Somers being upon the watch, had an apparition of a little round light, like a faint star, trembling and strearing along with a sparkling blaze, half the height upon the mainmast, and shooting sometimes from shroud to shroud, att mpting to settle as it were upon any of the four shrouds and three or four hours together or rather more than half the

1 William Shak espere - The Tempest, Act I, sc.11, lines 188-206. 
night it kept with us, running sometimes along the mainyard to the very end and then returning." (1)

In Hakluyt Voyageg (1598):

"This light continued aboard our ship about three hours flying from mast to mast and from top to top and sometimes it would be two or three places at once."

In Act II, scene 2, we find the only direct $r$ eference to the $\mathbb{N}$ ew World: Trinculo- "......... What have we here? (seeing Caliban) a man or a fish? Dead or alive? A fish: he smells like a fish; a very ancient and fish like smell; a kind of, not of the newest, Poor - John. A strange fish! Were I in England now, (as once I was) and had but this fish painted, not a holiday fool there was but would give a piece of silver: there would this monster make a man. When they will not give a doit to relieve a lame beggar, they will lay out ten to see a dead Indian." (2) Ben Jonson (1573-1637), the master of the Masques, used America and her supposed fabulous weal th

1 William Strachey - Irue Reportory (1610). See Introluction. 2 For description of capture of Indians, see ante, p.31. 
for the themes of his gorgeous productions.

The Vision of Delight (1617) was based on events which happened prior to the end of the Elizabethan era. Pocahontas, daughter of the Indian king Powhatan, was Jonson's inspiration for this Masque and was present on the occasion of its presentation at the king's command. (1)

The Alchemist (1609)contains allusions to the wealth of America. In the second act, Sir Epicure Mammon and his friend Surly are discussing the wealth of the $\mathbb{N e W}$ World:

Sir Marmon - "Come on sir, Now set Your foot on the shore, In novo orbe. Here's the rich Peru. And there within are the golden mines, Great Solomon's Ophir! He was sailing to 't Three years, but we have reached it in ten montho. This is the clay wherein to all my friends I will pronounce the happy word, Be rich."(2) Again in his conversation Sir Mammon declares that he "will purchase Devonshire and Cornwall and make them perfect Indies." (3)

John Fletcher (1576-1625), the dramatist, overlaps

1 Mary Sullivan - Court Masques of James I, p. 103.

2 Ben Jonson - The Alchemist, Act II, sc. 1 .

3 Ibid., Act II, sc. 1 . 
the period of Elizabeth and James I, but there lingers in his work the creative and romantic spirit of the Tudor regime rather than that of the realistic Stuart period.

The Sea Voyage (1622) is based on Shakesper e's The Tampest, but his idea of a female commonwealth, where the women had never seen a man, shows the influence of Hakluyt's In The Valley of Amazons.

The following speech is made by Rosellia, the governor of the Amazonian Portugals concerning the shipwrecked crew, washed up on her island: Rosellia - "Their lives shall fall a sacrifice to Vengeance,

I will look glorious in their bloods;

And the most noble spirit of Sebastian, That perish's by the pride of these French pirates, Shall smile in Heaven, and bless the hand that killed 'em."(l)

We quote the following parauraph from the Voyage of de Orellana which admirably describes Rosellia and her war rior-like tendencies:

"These women (Amazons) appear to be very tall, robust, fair with long twisted hair...... It was nothing new for women to fight and to use bows and arrows; as has I John Fletcher- The Sea Voyage, Act IV, sc. 2. 
been seen on some islands of Badlwents at Carthegena, where they displayed as much courage as men." (1)

From the foregoing discussion it is evident that exploration and discovery did have influence on the mizabethan writers. This influence did not come for the most part by direct communication with the voyagers themselves, but through the publication of their manuscripts. This work of translating and editing was done by such public spirited men as Richard Eden, Richard Hakluyt, and Samuel Purchas,

It must be noted, also, that the prevailing notion of the new world, which the mizabethan writers gl ean ed from these "Voyages", was its unbounded wealth. Not one author whom we have revi ewed fail ed to $r$ efer to this attribute of America and the Indies. To the Elizabethan mind, the new world was more fanciful than practical. There were fabulous stories of gold mountains, silver mines, giants, devils, and a fund of magic lore which lent itself to literature; but the veracity of it al1, Elizabethans believed, was not to be too closely questioned. Even the noble Raleigh was so ridiculed for his marvellous description of Guiana that he was forced to write his Discoverie of Guiana to convince the skeptical.

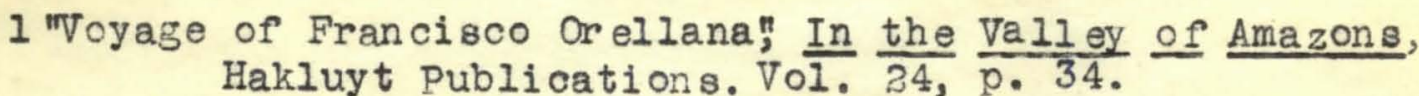


This study of the Flizabethan voyages and their relations to the literature of the time gives us a possible clue to the greatness of that era, in the form of a spirit of rivalry between words and deeds. The outcome of the era of adventure and discovery and territorial expansion we well know was an outburt of literary productivity, the like of which the world had never seen and possibly never will see again. 
Bacon, Francis - The New Atlantis

Cambridge History of English Literature (vol. 4)

Cawl ey, R. R. - Drayton and the Voyagers

- Warnor and the Voyagers

Chambers mglish Iiterature (vols. I-II)

Chapman, George - De Guiana Carmen Eoicum

- Masque of Virginia

Chaucer, Geoffrey - Canterbury Tales

Chronicles of America - Elizabethan Sea-Dogs (vol. 4)

Cooke, George W. - Browning Guide Book

Cram, Ralph A. - The Great Thousand Y ears

Drake, Francis - The World Encompassed

Drayton, Michael - To a Virginia Voyage

Fl etcher, John - The Sea Voyage

Foscarini, Antonio - Venetian State Papers 1603

Hakluyt, Richard - Dispatches of Cortez

- Diverg Voyages Touching the Discovery

- Fifth Letter of Hernan Cortez

- In the Valley of the Amazons

- Raleigh's Discovery of Guiana

- Reports on the Discovery of Peru

Hearnshaw, F.J.C. - Medi eval Contributions to Modern Givilization

Jameson, Mrs. - English Navigators

Jonson, Ben - The Alchemist (drama) 


$$
\begin{aligned}
\text { Kyd, Thomas } & - \text { I eronimo } \\
& \text { - The Spanish Tragedy }
\end{aligned}
$$

Lee, Sidney - Great Englishmen of the XVI Century

Lodge, Thomas - A Margarite of America

Mandeville, Sir John - Travels

Marlowe, Christopher - Tamburlaine

Monmouth, Geoffrey- Arthur Tales

Morl ey, John - English Men of Letters

Purchas, Samuel - His Pilgrims

Shak espere, William - Comedy of Errors

- Cymbeline

- Henry VIII

- Macbeth

- Merchant of Venice

- Midsummer Night's Dream

- $\underline{0 \text { the } 110}$

- Pericles Prince of Tyre

- The Tempest

- Twelfth Night

Smith, John - General History of Virginia etc. Spenser, Edmund - Faerie Queane

- Colin Clout Come Home Again

Sullivan, Mary - Court Masques of James I

Wyndham, George - Essays in Romantic Literature 